\title{
SYNTHESIS AND CHARACTERIZATION OF TIO 2 THIN FILM ELECTRODE BASED DYE SENSITIZED SOLAR CELL
}

\author{
(D)Varsha Yadav, (D)Swati Chaudhary, (D) Saral Kumar Gupta, (D) Ajay Singh Verma* \\ Department of Physics, Banasthali Vidyapith, Rajasthan, 304022 (India) \\ *Corresponding Author: ajay_phy@rediffmail.com \\ Received April 4, 2020; accepted May 26, 2020
}

Dye-Sensitized Solar Cells (DSSCs) are prominent alternative devices to conventional p-n junction silicon based solar cells because of their low fabrication cost and high-power conversion efficiency, good cost/efficiency ratio. In the present work, DSSC devices were made-up with fluorine doped tin oxide (FTO) glass substrate, a $\mathrm{TiO}_{2}$ compact layer was deposited on FTO, Ruthenium (II) dye (N719), an iodide - triiodide electrolyte and a platinum $(\mathrm{Pt})$ counter electrode. Photo anode with thin film layers of $\mathrm{TiO}_{2}$ and $\mathrm{Pt}$ counter electrode (photo-cathode) were prepared. Field emission electron microscope (FESEM) was employed to investigate the surface morphology of $\mathrm{TiO}_{2}$ layers. The DSSC device efficiency was evaluated by J-V characteristics. Fabricated devices were exhibited high power conversion efficiencies. The electrochemical impedance characteristics were analyzed by fitting the experimental results to the corresponding electrical equivalent circuit simulated data.

KEYWORDS: Solar cell, Nanocrystalline $\mathrm{TiO}_{2}$, Surface Morphology, Performance Parameters, Ruthenium Dye, impedance spectroscopy

State-of-the-art, the existing solar technologies are based on materials such as crystalline silicon, cadmium telluride materials. All of these materials have different problems and issues associated with the current technology. At present over $90 \%$ of the photovoltaic's (PVs) are silicon-based solar cells [1]. Which offer relatively high power conversion efficiencies (about 27\%) and about of 15-20 years operational lifetime. However, none of these approaches can address the key issue facing the PV market-the "cost to electricity output ratio" of solar generated electricity [2]. Also, the high energy cost to produce some of these PV negates the environmental benefits that can be gained. This clearly leaves the door ajar for a more economically viable material system to be produced to deliver the necessary infrastructure to harvest solar energy [3]. We believe that an ideal system suited to deliver such a solution is $\mathrm{TiO}_{2}$ based dye-sensitized solar cells. The combination of very low material cost, combined with solution-processable cheap production facilities lends itself to easy fabrication methods and low environmental costs on both energy for production and green materials, hugely support the claim that PVs offer the ideal material system to deliver a suitable mechanism for large area solar harvesting $[4,5]$.

DSSCs are often regarded as a third generation photovoltaic (PV) technology or an "emerging technology", that are promising alternative energy conversion devices for low cost energy conversion. Substantial progress has been made in fundamental research and technological application of DSSCs during the last two decades [6]. The combination of very low material cost, combined with solution-processable cheap production facilities lends itself to easy fabrication methods and low environmental costs on both energy for production and green materials, hugely support the claim that PVs offer the ideal material system to deliver a suitable mechanism for large area solar harvesting. The long term reliability parameters can be achieved by the incorporation of suitable Nanomaterial which provide enough mechanical strength and flexibility for roll-to-roll process of flexible device [7].

The concept of DSSCs originated from the photosynthesis phenomenon in the plants, where chlorophyll, an organic compound, absorbs the sunlight and initiates photosynthesis process. The photovoltaic effect in DSSCs was first demonstrated in the early 1970s, but instability was their biggest problem. Though the efficiency improved in subsequent years but poor stability remained a big problem [8,9]. In 1991, O'Regan and Gratzel presented the modern version of is composed of porous layer of titanium dioxide nanoparticles, covered with a molecular dye that absorbs sunlight, like the chlorophyll in green leaves. The titanium dioxide is immersed under an electrolyte solution, above which is a platinum- based catalyst [10]. As in a conventional alkaline battery an anode (the titanium dioxide) and a cathode (the platinum) are placed on either side of a liquid conductor (the electrolyte). The sunlight passes through the transparent electrode into the dye layer, where it can stimulate the electrons floating in titanium dioxide. The electrons flow toward the transparent electrode, where they are collected to give the power to the load [11]. After flowing through the outer circuit, they are presented again in the cell on the metal electrode on the back flowing in electrolyte [12,13]. The electrolyte then transports the electrons back to the dye molecules [14].

In this work, DSSCs were fabricated using $\mathrm{TiO}_{2}$ electrode as a photoanode and Pt electrode as a Photocathode, here photoanode was used with the $\mathrm{TiO}_{2}$ paste and solar cell performance was analyzed. We have examined the development of the device performance like short circuit current density (Jsc), open circuit voltage (Voc) and solar energy to conversion efficiency $(\eta)$. We also excluded TiO2 film morphology with the help of FESEM technique and some electrical parameters by impedance technique. 


\section{EXPERIMENTAL SECTION}

Titanium dioxide $\left(\mathrm{TiO}_{2}\right.$ ), Fluorine -doped tin oxide (FTO) coated glass substrate (sheet resistance $\sim 8-12 \Omega / \mathrm{cm}^{2}$ ), Dye (N719), Platinum paste, Lithium iodide (LiI), Iodine $\left(\mathrm{I}_{2}\right)$, 1butyle-3methyle inidazolium iodide (BMIT), 4-tert butyl pyridine, Acetonitrile and valeronitrile. All chemicals purchased from sigma Aldrich and used without any purification.

Synthesis of Dye precursor solution. Dye solution was prepared by dissolving $36 \mathrm{mg} \mathrm{N}_{719}$ dye in $100 \mathrm{ml}$ absolute ethanol. Shake well until the solution dissolved properly.

Synthesis of Electrolyte precursor solution. Electrolyte solution was prepared by dissolving $0.1 \mathrm{M} \mathrm{LiI}, 0.05 \mathrm{M}$ iodine, 0.6 BMIT, 0.5 4-tert butyl pyridine in (17:3) $\mathrm{ml}$ ratio of Acetonitrile - Valeronitrile by stirring at room temperature until obtain uniform solution.

Device Fabrication and characterization. A Systematic DSSCs consists of several majors parts like Photoanode, Dye, Electrolyte, and Photocathode which is mentioned in the diagrammatic structure of DSSC shown below as Figure 1. Firstly, for the synthesis of photoanode, FTO glass substrate was cleaned with DI water acetone and iso-propanol by ultrasonic bath process [15]. A scotch tape was paste on the conducting side of FTO then, $\mathrm{TiO}_{2}$ films were applied with the help of Doctor Blade technique.

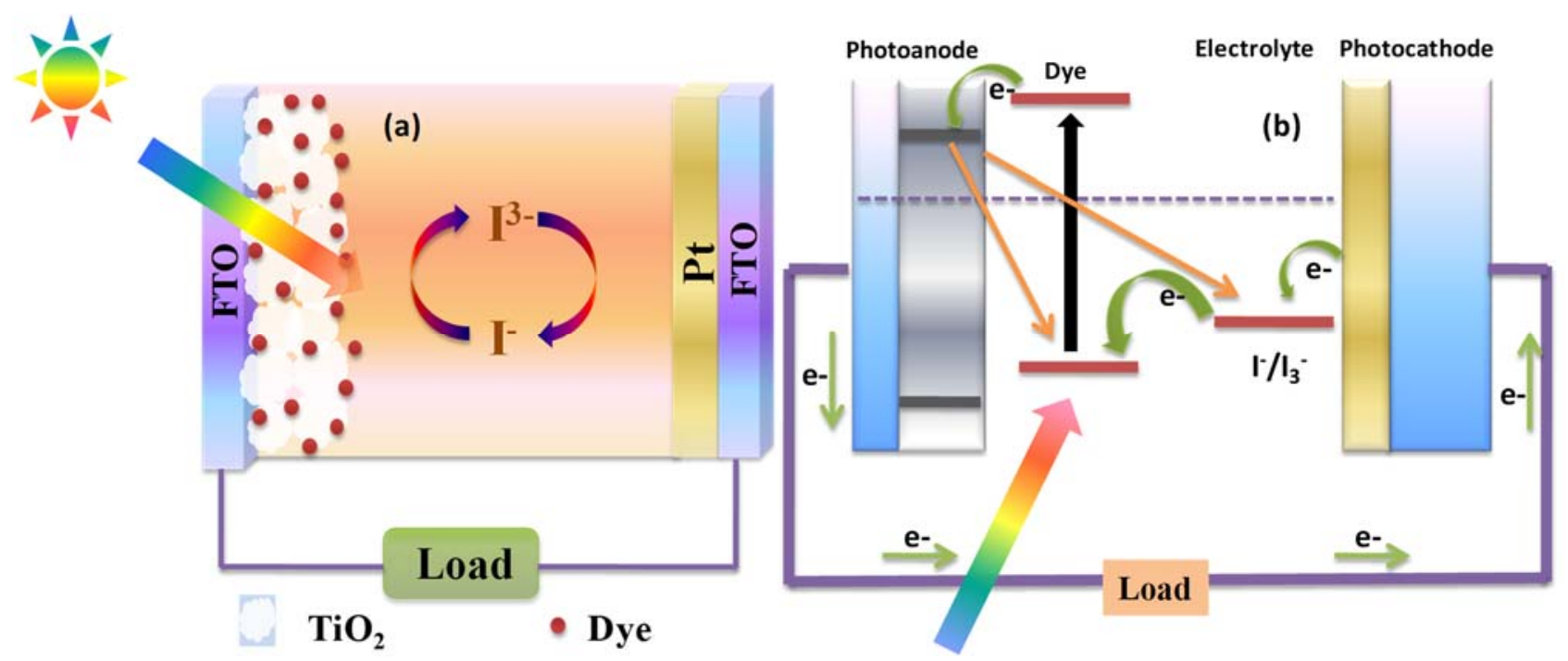

Figure 1. (a) Reveals the structure of device and (b) associated energy level diagram.

The deposited films were annealed at $470^{\circ} \mathrm{C}$ for 45 minutes in high temperature furnace. The $\mathrm{TiO}_{2}$ films were deposited immersed in a dye solution for 24 hours in dark. The Pt also deposited on FTO substrate by using doctor blade method as a counter electrode and for 30 minutes annealed at $500^{\circ} \mathrm{C}$. The $\mathrm{TiO}_{2}$ films were formed as dye loaded photoanode and counter electrode as Pt deposited substrate [16,17]. Each sandwich cell was held in place with the help of two heavy duty clips on both opposites' sides of electrode. Liquid electrolyte was introduced between both [18]. Along with basic electron transfer processes in DSSC prospects of a state-of-art device based on dye adsorbed on $\mathrm{TiO}_{2}$ and $\mathrm{I}^{-} / \mathrm{I}^{3-}$ in the form of redox pairs electrolyte is shown in Figure 1(a). On illumination, an electron photo generated by dye molecules as like in photosynthesis [19]. By photon (hv) absorption a dye molecule is excited whereas electron is excited from HOMO into LUMO subsequently, the free electron is injected into the $\mathrm{TiO}_{2}$ conduction band and left the oxidized dye molecule. Then, the electron reach the Pt catalyst layer where redox reactions occur by the recombination with holes with in the electrolyte by reducing tri iodide $\left(\mathrm{I}^{3-}\right)$ to iodide ion $\left(\mathrm{I}^{-}\right)$. However, the negative charge of I, in the final step, diffuses back to the dye molecules and it will react with the oxidized molecule. Thus, it completes the electrical cycle and repeats again. Besides this process some recombination happened like recombination of injected electron in the $\mathrm{TiO}_{2}$ with either acceptors or oxidized dyes, which degrade the performance of the cell $[20,21]$.

\section{RESULTS AND DISCUSSION}

The surface microstructure features of the film were characterized using Field Emission Scanning Electron Microscope (FESEM) as shown in the Figure 2. FESEM image of the $\mathrm{TiO}_{2}$ film sample annealed at $470^{\circ} \mathrm{C}$ for $45 \mathrm{~min}$. The image reveals a film that was crack-free, uniform and smooth on the surface. It also shows that the $\mathrm{TiO}_{2}$ thin film possesses a nanocrystalline and nonporous structure which consists of nanoparticles.

The photovoltaic performance of the DSSCs based on Titanium Dioxide thin film photoanode were investigate under a simulated solar irradiation of $100 \mathrm{~mW} \mathrm{~cm}^{-2}$ (AM 1.5G) [22,23]. Figure 3(a) display the measured J-V characteristics of solar cell based on $\mathrm{TiO}_{2}$ films and 3(b) shows different efficiencies of DSSC based on wavelength. The corresponding photovoltaic parameters short circuit current $\left(\mathrm{J}_{\mathrm{sc}}\right)$, fill factor $(\mathrm{FF})$, open circuit voltage $\left(\mathrm{V}_{\mathrm{oc}}\right)$, and conversion efficiency $(\eta)$ for DSSCs for the $\mathrm{TiO}_{2}$ films has been calculated. We have found the values of cell parameters such as; $\mathrm{V}_{\mathrm{oc}}, \mathrm{J}_{\mathrm{sc}}, \mathrm{FF}$, 
$\mathrm{I}_{\max }, \mathrm{V}_{\max }, \mathrm{P}_{\max }$ and efficiency are of $0.60 \mathrm{~V}, 3.337 \mathrm{~mA} / \mathrm{cm}^{2}, 56.13 \%, 0.00289 \mathrm{~A}, 0.4704 \mathrm{~V}, 1.36$ and $1.13 \%$. The performance of cell is considerable at low cost DSSC technology available today [24]. On other hand we have found different values of efficiency at different range of wave length as mentioned in figure 3(b), and are continuously increase. From all the parameters we have measured overall highest efficiency of fabricated cell is $1.5 \%$ at $900-1100 \mathrm{~nm}$ range of wavelength. Photovoltaic performances are influenced by the dye adsorption solvent [25].

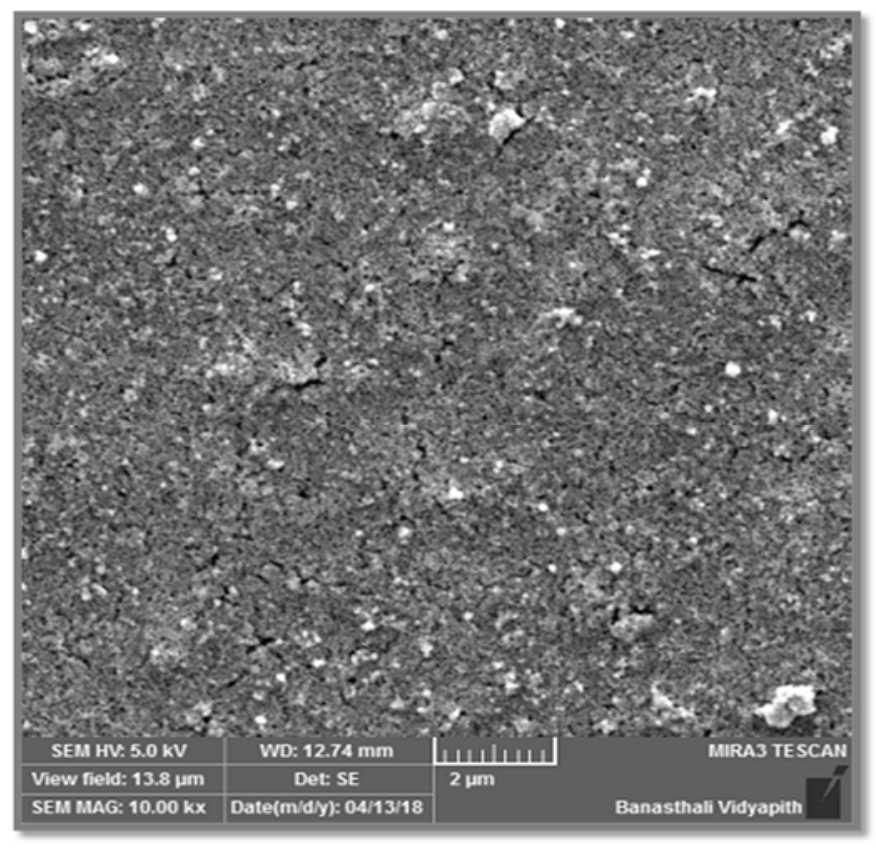

Figure 2. FESEM image of $\mathrm{TiO}_{2}$ thin film deposited on glass substrate

The adsorption behavior of dye is significant at this wavelength. Electrochemical impedance spectroscopy (EIS) is a beneficial technique to investigate the internal impedance of photovoltaic device [26], such as DSSC. Electrochemical interface of split in three parallel circuits, additionally the equivalent circuit of DSSC is related to the experimental result of the Nyquist plot as display in Figure 4(a).
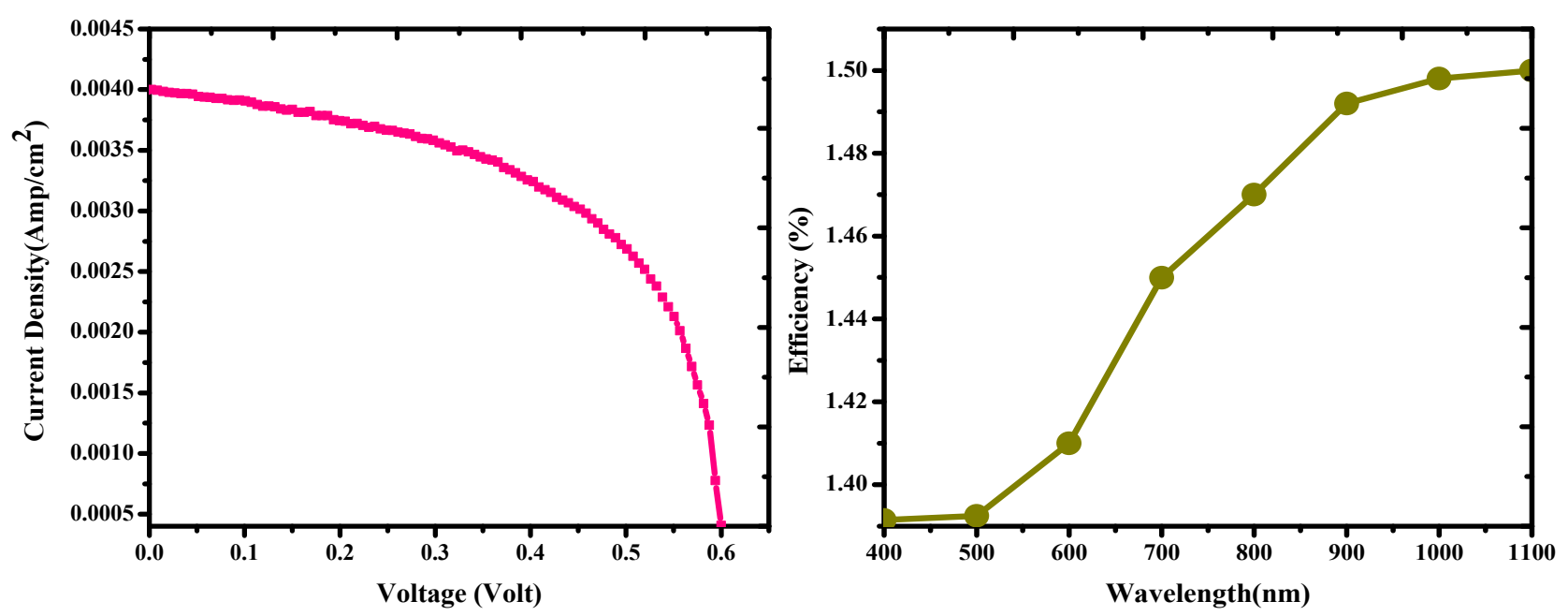

Figure 3. (a) - The J-V curve under illumination of DSSC based on $\mathrm{TiO}_{2}$ film. (b) - Efficiency performance based on different range of wavelength.

In Nyquist plot equivalent circuit in the horizontal axis represent the serial resistance $\left(\mathrm{R}_{1}\right)$ between wire and substrate, from the impedance spectra represent resistance $\left(R_{2}\right)$ and $\left(R_{3}\right)$ at interface between electrolyte and Pt counter electrode and as well as between electrolyte and $\mathrm{TiO}_{2}$ film. On the other side at the interface $\mathrm{C}_{1}$ shows the double layer capacitance between electrolyte and $\mathrm{Pt}$ counter electrode and as well as between electrolyte and $\mathrm{TiO}_{2}$ film $[27,28]$. The values of all the parameters of Nyquist plots of DSSC based on $\mathrm{TiO}_{2}$ photoanode with the equivalent circuit are summarized in Table. 

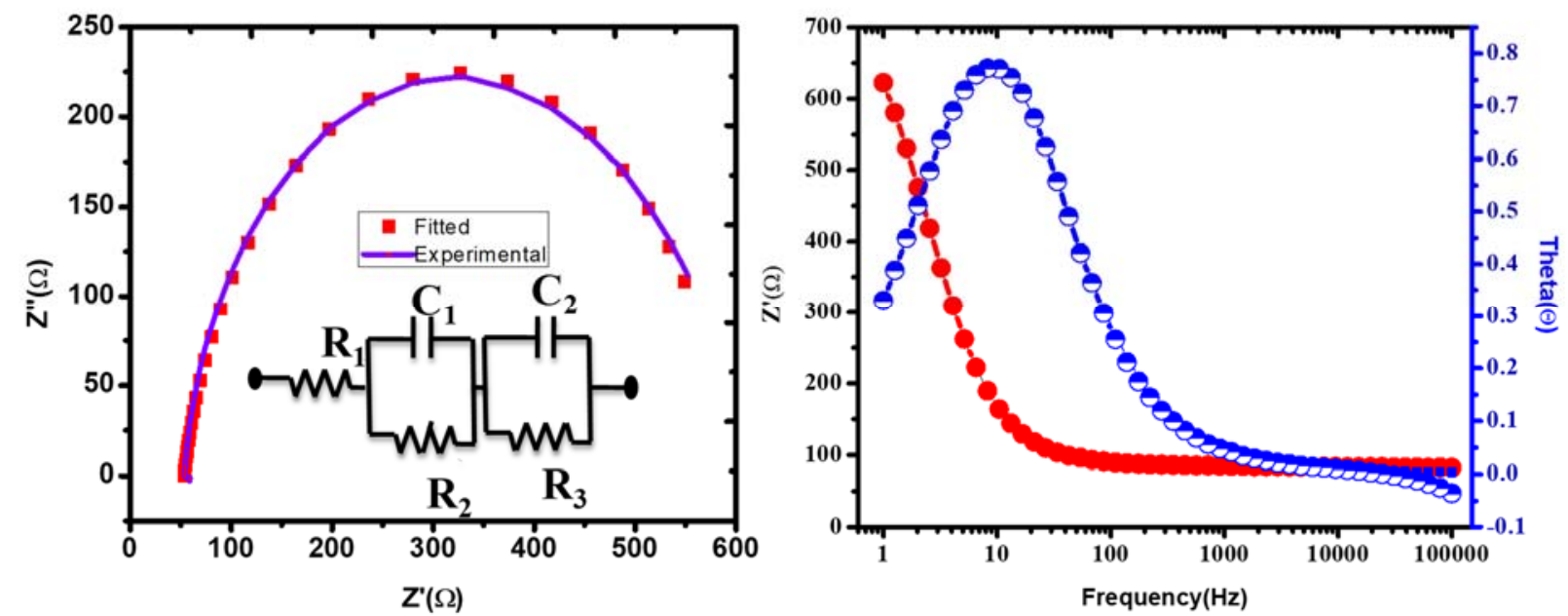

Figure 4. (a): The Nyquist plots of DSSC based on $\mathrm{TiO}_{2}$ photoanode with the equivalent circuit of DSSC; (b) Bode plot of DSSC based on $\mathrm{TiO}_{2}$ photoanode.

Table

The resistance and capacitance values of equivalent circuit for $\mathrm{DSSC}$ based on $\mathrm{TiO}_{2}$ photoanode

\begin{tabular}{|c|c|c|c|c|c|}
\hline Sample & $\mathbf{R}_{\mathbf{1}}(\mathbf{\Omega})$ & $\mathbf{C}_{\mathbf{1}}(\mathbf{m F})$ & $\mathbf{C}_{\mathbf{2}}(\mathbf{m F})$ & $\mathbf{R}_{\mathbf{2}}(\mathbf{\Omega})$ & $\mathbf{R}_{\mathbf{3}}(\mathbf{\Omega})$ \\
\hline $\mathrm{TiO}_{2}$ & 85.91 & 0.125 & 0.149 & 132.32 & 494.62 \\
\hline
\end{tabular}

In the bode plot of cell based on photoanode $\mathrm{TiO}_{2}$ under the solar irradiation, the frequency was shifted in higher frequency region with the $\mathrm{TiO}_{2}$ photoanode as shows in figure 4(b).According to curve recombination charge transfer processes at the $\mathrm{TiO}_{2} /$ dye/electrolyte interface is low and enhance the electron transmission $[29,30]$. On the other hand illumination condition $f_{\max }$ is inversely proportional to the electron transport time as $\tau_{\mathrm{s}}=1 /\left(2 \pi \mathrm{f}_{\max }\right)$, increment in $\mathrm{f}_{\max }$ shows the increased rate of charge transport process in DSSC [24]. Hence, with the reduced value $\tau_{\mathrm{s}}$ of indicates that the electrons reaches at FTO electrode at a faster rate, so that we can improve the performance of DSSC by further modification.

\section{SUMMARY AND CONCLUSIONS}

We have successfully fabricated and characterized Dye sensitized solar cell based on $\mathrm{TiO}_{2}$ photoactive layer. Which shows the PCE of $1.13 \%, \mathrm{~J}_{\mathrm{sc}}$ of $3.337 \mathrm{~mA} / \mathrm{cm}^{2}, \mathrm{~V}_{\text {oc }}$ of $0.60 \mathrm{~V}$ and FF of $56.13 \%$, and overall highest PCE is $1.5 \%$ on 900 to1100 $\mathrm{nm}$ wavelength ranges. The performance of cell is good at simple laboratory condition, but we can improve photovoltaic performance by using this methodology. The EIS analysis observes that the resistance between electrolyte and $\mathrm{TiO}_{2}$ film increase, which indicates that a larger resistance at the interface between $\mathrm{TiO}_{2}$ film and electrolyte is beneficial for suppression of charge recombination. Hence, we can achieve enhancement in performance of DSSC by modification in $\mathrm{TiO}_{2}$ (like doping and annealing etc) and Dye and electrolyte (natural sources achieved by immediate environment).

\section{ACKNOWLEDGMENTS}

The authors would like to great full financial support from DST, India under CURIE program (grant No. SR/CURIE- Phase$\mathrm{III} / 01 / 2015(\mathrm{G})$ ) and the Ministry of Human Resource Development (MHRD) and Department of Science (DST curie) for providing the financial and instrumental support respectively.

\section{ORCID IDs}

(DVarsha Yadav https://orcid.org/0000-0003-1990-5910; (CSwati Chaudhary https://orcid.org/0000-0002-8504-3602,

(DSaral Kumar Gupta https://orcid.org/0000-0002-0446-8984; (1) Ajay Singh Verma https://orcid.org/0000-0001-8223-7658

\section{REFERENCES}

[1] O. K. Simya, M. Selvam, A. Karthik, V. Rajendran, Synth. Met. 188, 124-129 (2014), https://doi.org/10.1016/j.synthmet.2013.12.005.

[2] S. Battersby, Proc. Natl. Acad. Sci. 116, 7-10 (2019), https://doi.org/10.1073/pnas.1820406116.

[3] M. Grätzel, J. Photochem. Photobiol. C Photochem. Rev. 4, 145-153 (2003), https://doi.org/10.1016/S1389-5567(03)00026-1.

[4] K. Ebrahim, Sol. Cells - Dye. Devices, InTech. 171-204 (2012), https://doi.org/10.5772/19749.

[5] W. Jarernboon, S. Pimanpang, S. Maensiri, E. Swatsitang, and V. Amornkitbamrung, Thin Solid Films. 517, 4663-4667 (2009), https://doi.org/10.1016/j.tsf.2009.02.129.

[6] D. Wei, Int. J. Mol. Sci. 11, 1103-13 (2010), https://doi.org/10.3390/ijms11031103.

[7] S. Bose, V. Soni, and K.R. Genwa, Int. J. Sci. Res. Publ. 5, 2250-3153 (2015), http://www.ijsrp.org/research-paper0415.php? $\mathrm{rp}=\mathrm{P} 403882$.

[8] B.O. Regan, and M. Gratzel, Nature, 353, 737-740 (1991), https://doi.org/10.1038/353737a0.

[9] C. Cavallo, F. Di Pascasio, A. Latini, M. Bonomo, and D. Dini, J. Nanomater. 2017, 1-31 (2017), https://doi.org/10.1155/2017/5323164.

[10] J. Gong, K. Sumathy, Q. Qiao, and Z. Zhou, Renew. Sustain. Energy Rev. 68, 234-246 (2017), https://doi.org/10.1016/j.rser.2016.09.097. 
[11] S. Yun, J.N. Freitas, A.F. Nogueira, Y. Wang, S. Ahmad, and Z.S. Wang, Prog. Polym. Sci. 59, 1-40 (2016), https://doi.org/10.1016/j.progpolymsci.2015.10.004.

[12] M. Eslamian, and J. Newton, Coatings. 4, 85-97 (2014), https://doi.org/10.3390/coatings4010085.

[13] A. Jena, S.P. Mohanty, P. Kumar, J. Naduvath, V. Gondane, P. Lekha, J. Das, H.K. Narula, S. Mallick, and P. Bhargava, Trans. Indian Ceram. Soc. 71, 1-16 (2012), https://doi.org/10.1080/0371750X.2012.689503.

[14] K. Miettunen, J. Vapaavuori, A. Tiihonen, A. Poskela, P. Lahtinen, J. Halme, and P. Lund, Nano Energy. 8, 95-102 (2014), https://doi.org/10.1016/j.nanoen.2014.05.013.

[15] B. Siwach, D. Mohan, S. Sharma, and D. Jyoti, Bull. Mater. Sci. 40, 1371-1377 (2017), https://doi.org/10.1007/s12034-017-1492-z.

[16] T. Phonkhokkong, T. Thongtem, S. Thongtem, A. Phuruangrat, and W. Promnopas, Dig. J. Nanomater. Biostructures. 11, 81-90 (2016), http://www.chalcogen.ro/81_Phonkhokkong.pdf.

[17] T.V. Nguyen, H.C. Lee, and O.B. Yang, Sol. Energy Mater. Sol. Cells. 90, 967-981 (2006), https://doi.org/10.1016/j.solmat.2005.06.001.

[18] S. Xuhui, C. Xinglan, T. Wanquan, W. Dong, and L. Kefei, AIP Adv. 4, 031304 (2014), https://doi.org/10.1063/1.4863295.

[19] S. Widodo, G. Wiranto, and M.N. Hidayat, Energy Procedia. 68, 37-44 (2015), https://doi.org/10.1016/j.egypro.2015.03.230.

[20] A. Karmakar, and J. Ruparelia, in International Conference on Current Trends in Technology, NUiCONE, (IEEE, Piscataway, 2011), pp. 1-6.

[21] D.L. Domtau, J. Simiyu, E.O. Ayieta, L.O. Nyakiti, B. Muthoka, and J.M. Mwabora, Surf. Rev. Lett. 24, 1750065 (2017), https://doi.org/10.1142/S0218625X17500652.

[22] B. Alfa, M.T. Tsepav, R.L. Njinga, and I. Abdulrauf, Appl. Phys. Res. 4, 48-56 (2012), https://doi.org/10.5539/apr.v4n1p48.

[23] A.F. Ole, G.N.C. Santos, and R.V Quiroga, Int. JSER, 3, 1-7 (2012).

[24] L. Wei, P. Wang, Y. Yang, Z. Zhan, Y. Dong, W. Song, and R. Fan, Inorg. Chem. Front. 5, 54-62 (2018), https://doi.org/10.1039/C7QI00503B.

[25] Z.A. Shah, K. Zaib, and A. Khan, J. Fundam Renewable Energy Appl. 7, 4-6 (2017).

[26] H. Yu, S. Zhang, H. Zhao, G. Will, and P. Liu, Electrochim. Acta. 54, 1319-1324 (2009), https://doi.org/10.1016/j.electacta.2008.09.025.

[27] J.C. Chou, C.M. Chu, Y.H. Liao, C.H. Lai, Y.J. Lin, P.H. You, W.Y. Hsu, C.C. Lu, and Y.H. Nien, IEEE J. Electron Devices Soc. 5, 32-39 (2017).

[28] A. Upadhyaya, C.M. Singh Negi, A. Yadav, S.K. Gupta, and A.S. Verma, Superlattices Microstruct. 122, 410-418 (2018).

[29] N. Sharma, C.M.S. Negi, A.S. Verma, and S.K. Gupta, J. Electron. Mater. 47, 7023-7033 (2018), https://doi.org/10.1007/s11664018-6629-3.

[30] A.S. Verma, A. Upadhyaya, S.K. Gupta, A. Yadav, and C.M.S. Negi, Semicond. Sci. Technol. 33, 065012 (2018), https://doi.org/10.1088/1361-6641/aac066.

\section{СИНТЕЗ І ХАРАКТЕРИСТИКИ СОНЯЧНОГО ЕЛЕМЕНТУ 3 ТОНКОПЛІВКОВИМ ТіО ЕЛЕКТРОДОМ СЕНСИБІЛІЗОВАНОГО БАРВНИКОМ}

Варша Ядав, Сваті Чаддхарі, Сарал Кумар Гупта, Аджай Сінгх Верма*

Фізичний факультет, 304022 Раджастан, Банасталі Відяпіт, Індія

Сенсибілізовані барвником сонячні елементи (DSSC) є значною альтернативою звичайним сонячним елементам на основі кремнію $з$ p-n-переходом через їх низьку вартість виготовлення і високу ефективність перетворення енергії, гарного співвідношення ціна/ефективність. У цій роботі пристрої DSSC були виготовлені зі скляної підкладки, яка містить оксид олова легованого фтором (FTO), компактного шару $\mathrm{TiO}_{2}$ нанесеного на $\mathrm{FTO}$, рутенієвого (II) барвника $\left(\mathrm{N}_{719}\right)$, йодидтрійодідного електроліту і платинового (Pt) протиструминного електрода. Були підготовлені фотоанод 3 тонкоплівковими шарами $3 \mathrm{TiO}_{2}$ і платиновий протиструминний електрод (фотокатод). Польовий емісійний електронний мікроскоп (FESEM) використовувався для дослідження морфології поверхні шарів $3 \mathrm{TiO}_{2}$. Ефективність пристроїв DSSC (сенсибілізовані барвником сонячні елементи) оцінювалася за характеристиками J-V. Виготовлені пристрої показали високу ефективність перетворення енергії. Характеристики електрохімічного імпедансу були проаналізовані шляхом приведення експериментальних результатів до відповідних даних, змодельованих на основі еквівалентної електричної схеми.

КЛЮЧОВІ СЛОВА: сонячний елемент, нанокристалічний ТiO2, морфологія поверхні, робочі характеристики, рутенієвий барвник, імпедансна спектроскопія

\section{СИНТЕЗ И ХАРАКТЕРИСТИКИ СОЛНЕЧНЫХ ЭЛЕМЕНТОВ С ТОНКОПЛЕНОЧНЫМ ТіО ЭЛЕКТРОДОМ СЕНСИБИЛИЗИРОВАННОГО КРАСИТЕЛЕМ}

Варша Ядав, Свати Чаддхари, Сарал Кумар Гупта, Аджай Сингх Верма*

Физический факультет, 304022 Раджастан, Банастали Видяпит, Индия

Сенсибилизированные красителем солнечные элементы (DSSC) являются существенной альтернативой обычным солнечным элементам на основе кремния c p-n-переходом из-за их низкой стоимости изготовления и высокой эффективности преобразования энергии, хорошего соотношения цена/эффективность. В настоящей работе устройства DSSC были изготовлены из стеклянной подложки содержащей оксид олова легированного фтором (FTO), компактного слоя $\mathrm{TiO}_{2}$ нанесенного на FTO, рутениевого (II) красителя $\left(\mathrm{N}_{719}\right)$, йодид-трийодидного электролита и платинового $(\mathrm{Pt})$ противоточного электрода. Подготовлены фотоанод с тонкопленочными слоями из $\mathrm{TiO}_{2}$ и платиновый противоточный электрод (фотокатод). Полевой эмиссионный электронный микроскоп (FESEM) использовался для исследования морфологии поверхности слоев из $\mathrm{TiO}_{2}$. Эффективность устройств DSSC оценивалась по характеристикам J-V. Изготовленные устройства показали высокую эффективность преобразования энергии. Характеристики электрохимического импеданса были проанализированы путем приведения экспериментальных результатов к соответствующим данным, смоделированным на основе эквивалентной электрической схемы.

КЛЮЧЕВЫЕ СЛОВА: солнечный элемент, нанокристаллический $\mathrm{TiO}_{2}$, морфология поверхности, рабочие характеристики, рутениевый краситель, импедансная спектроскопия. 